\title{
Petrografie xenolitů vyvřelých hornin v neovulkanitech z lomu Bučník u obce Komňa
}

\author{
Petrography of xenoliths of igneous rocks in neovolcanites from the quarry Bučník \\ near the Komňa village
}

Michaela Hašková, Kamil Kropáč $\square$

Katedra geologie, PřF UP, 17. listopadu, 77146 Olomouc

Key words:

Outer Western Carpathians, Flysch Belt, Magura Nappe, Bílé Karpaty Unit, neovolcanites, xenoliths

$\rightrightarrows$ kamil.kropac@upol.cz

Editor:

David Buriánek

\begin{abstract}
Neovolcanites from the Uhersky Brod area sporadically enclose $\mathrm{cm}$ to $\mathrm{dm}$ large xenoliths of plutonic rocks. This paper focuses on characterization of xenoliths from the Bučník hill which are enclosed in trachyandesites by using classic petrographic methods. Based on mineral composition and textural features of main rock-forming minerals, the studied xenoliths can be classified as fine-to coarse-grained pyroxenic-amphibolic gabbros or diorites, respectively. They consist mainly of intermediate polysynthetically twinned plagioclase (andesine to labradorite; $A n_{44-55}$ ) and yellow-brown pleochroic magnesiohastingsite to pargasite $\left(X_{M g}=0.64-0.75 ; \mathrm{Si}=6.09-6.29 \mathrm{apfu} ; \mathrm{Ti}=0.30-0.42 \mathrm{apfu}\right)$. Relicts of diopside $\left(X_{M g}=0.70-0.80 ; \mathrm{Ti}=0.01-0.03 \mathrm{apfu} ; \mathrm{Na}=0.03-0.04 \mathrm{apfu}\right)$, brown strongly pleochroic phlogopite leaflets $\left(X_{M g}=0.58-0.65 ; S i=5.51-5.60\right)$, apatite columns (predominantly fluorapatite; $F=0.43-0.77 a p f u)$ and $K$-feldspar $\left(A b_{16-17} O r_{82-84} A n_{00-01}\right)$ grains are less frequent. Amphiboles sporadically enclose round or tabular inclusions of labradorite to bytownite $\left(A n_{64-72}\right)$ and subhedral olivine $\left(\mathrm{Fo}_{64}\right)$. Xenoliths are similarly to host trachyandesites affected by superimposed hydrothermal alteration. Secondary minerals represent acid plagioclase $\left(A n_{05-10}\right)$, chlorites (clinochlore; $X_{M g}=0.55-0.67 ; S i=3.13-3.29$ apfu), carbonates (calcite and siderite), Ti-minerals (ilmenite, rutile and titanite), sulphides (pyrite and chalcopyrite) and less frequently quartz. The genetic affinity of xenoliths and the host neovolcanites is evidenced by the similarity in mineral composition and whole-rock chemistry. Xenoliths can be interpreted either as material from deeper parts of the magma chamber, or more probably as crystal cumulates (i.e. equivalents of cumulate gabbros).
\end{abstract}

\section{Úvod}

Xenolity vyvřelých hornin $\mathrm{v}$ alkalických neovulkanitech Uherskobrodska představují jedinečný materiál, jehož studiem lze přispět k porozumění magmatických procesů v oblasti. Základy výzkumu xenolitů ve vyvřelinách Uherskobrodska položily práce Krystka $(1955,1958)$, který popsal různé typy xenolitů hlubinných a žilných hornin lišících se stavbou a relativním zastoupením hlavních horninotvorných minerálů. První podrobnější studii představuje až práce Haškové (2018), opírající se zejména o EDX analýzy minerálů a zhodnocení celkového chemismu xenolitů a hostitelských trachyandezitů z lomu Bučník. Přes velký přínos zmíněného díla nemohly být některé otázky s ohledem na limity EDX analýzy zodpovězeny. Tato práce navazuje na zjištění Haškové (2018) a prezentuje nová data chemismu minerální asociace xenolitů a hostitelských hornin a nové interpretace. 


\section{Geologická situace}

Sedimentární horniny odkryté lomem Bučník u obce Komňa náleží $\mathrm{z}$ regionálně-geologického hlediska k vlárskému vývoji bělokarpatské jednotky, která je součástí magurské skupiny př́krovů flyšového pásma Vnějších Západních Karpat (Stráník et al. 1993). Vlárský vývoj buduje zejména horské oblasti Bílých Karpat a má menší stratigrafický rozsah než hlucký vývoj (barrem až střední eocén), který představuje část bělokarpatské jednotky na západ od nezdenického zlomu. Sedimentace ve vlárském vývoji započala na konci spodní křídy (alb) a prakticky až do konce svrchní kř́ídy si udržela jednotný charakter. Usazovaly se zde zelené a červené nevápnité jílovce a jemnozrnné laminované pískovce kaumberského souvrství. Koncem campanu se začínají ukládat i drobně až středně zrnité pískovce s vysokým podílem karbonátů a siltové jílovce javorinského souvrství. Tento trend pokračoval až do spodního paleocénu (dan), v jehož průběhu postupně převládá středně rytmická flyšová sedimentace šedých vápnitých jílovců a modrošedých pískovců svodnického souvrství. K ukončení sedimentace ve vlárském vývoji došlo ve spodním eocénu (Stráník et al. 1993, 1996; Švábenická et al. 1997). Celá sedimentární sekvence byla následně vyvrásněna a přesunuta $\mathrm{v}$ rámci helvétské fáze alpinské orogeneze v oligocénu. Finální podobu prríkrovu dotvořily pohyby během sávské a štýrské fáze v miocénu. Vrásová struktura flyše byla narušena podélnými a př́ičnými zlomy, které posloužily jako přívodní dráhy magmatu. Nejvýznamnější př́ičnou strukturu v oblasti představuje nezdenický zlomový systém, který kopíruje poruchy brunovistulika v podloží (Stráník et al. 1993; Picha et al. 2006; Krejčí, Poul 2010; Hrouda et al. 2015).

Neoidní alkalické vulkanity vystupují na povrch podél nezdenického zlomu v bělokarpatské a bystrické jednotce a poblíž jejich společného styku a kontaktu s jednotkou račanskou (obr. 1). Z chemického hlediska

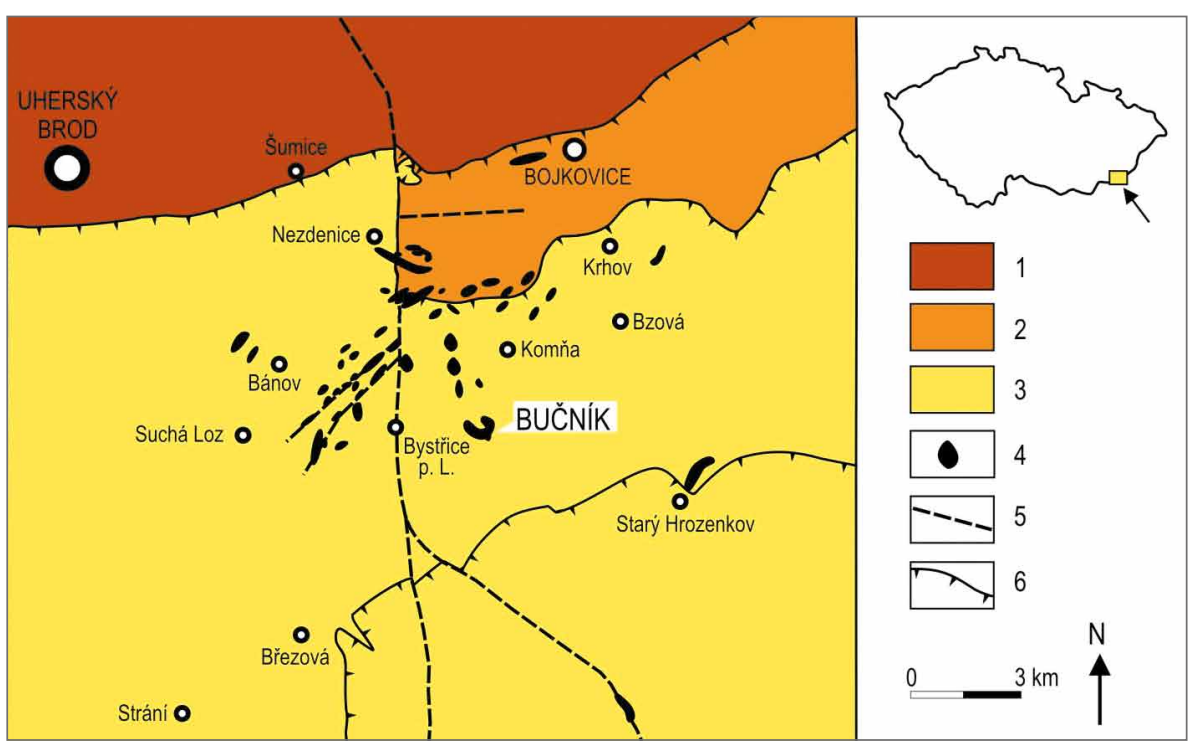

Obr. 1: Geologická pozice lokality Bučník v rámci magurské skupiny příkrovů. 1 - račanská jednotka; 2 - bystrická jednotka; 3 - bělokarpatská jednotka; 4 - subvulkanické horniny; 5 hlavní zlom; 6 - ověrený násun.

Fig. 1: Geological position of the Bučník site in the Magura Nappe. 1 - Rača Unit; 2 - Bystrica Unit; 3 - Bilé Karpaty Unit; 4 - subvolcanic rocks; 5 - main fault; 6 - verified thrust. lze tyto horniny klasifikovat jako bazalty, trachybazalty, bazaltické trachyandezity, trachyandezity a trachyty až trachydacity (Shrbený 1974; Krejčí ed. 1990; Adamová et al. 1995; Fediuk, Gürtlerová 2006; Nejbert et al. 2012; Hrouda et al. 2015; Hašková 2018; Buriánek, Kropáč 2019). Stáří neovulkanitů odpovídá na základě radiometrického datování K/Ar metodou střednímu badenu až spodnímu sarmatu. Přichystal et al. (1998) určili stáří na 14,8 \pm 0,4 My (metodou stanovení obsahu ${ }^{40} \mathrm{Ar}$ izotopovým ředěním), respektive na $13,5 \pm 0,4 \mathrm{My}$ (volumetricky). Následné datování Pécskaye et al. (2002) poskytlo srovnatelné výsledky 14,76 $\pm 1,18$ až 13,36 $\pm 0,53 \mathrm{My}$.

Na vrcholu Bučníku je tř́ietážovým lomem odkryto subvulkanické těleso cedrového lakolitu, které proniká $\mathrm{v}$ podobě pravých a ložních žil s vrtně ověřenou nepravou mocností 63,8 m (Adamová et al. 1995) do flyšových sedimentů. Žíly jsou tvořeny převážně pyroxenicko-amfibolickým trachyandezitem, prrítomny jsou i světlejší typy odpovídající trachytu až trachydacitu. Tyto horniny jsou obvykle postiženy středně silnou až silnou hydrotermální přeměnou (propylitizací) a zvětráváním rychle mění barvu z šedobílé na světle oranžovou (Krystek 1955; Přichystal 1993; Hrouda et al. 2015; Ulmanová 2015; Štrublíková 2015; Hašková 2018). Z výzkumů fluidních inkluzí v hydrotermálních mineralizacích na lokalitě vyplývá, že alteraci způsobily jednak nízkosalinní hydrotermální roztoky obsahující chloridy $\mathrm{Na}$, popr. $\mathrm{K}$ a $\mathrm{Mg}$, jednak středněsalinní až vysokosalinní hydrotermální roztoky s chloridy $\mathrm{Na}$ a Ca. Zdrojem nízkosalinních roztoků byla pravděpodobně mořská nebo diagenetická voda, která se mísila s vodou meteorickou. Středněsalinní až vysokosalinní roztoky byly interpretovány jako magmatické solanky či fluida zahuštěná o soli uvolněné hydratačními reakcemi při přeměně živců a tmavých minerálů v trachyandezitech (Ulmanová 2015). Okolní sedimenty představují jemnozrnné až středně zrnité modrošedé pískovce a jílovce svodnického souvrství, které se v okolí intruze tepelně přeměnily na porcelanit (Adamová et al. 1995; Hrouda et al. 2015).

\section{Metodika}

Petrografickému studiu bylo podrobeno celkem 14 vzorků xenolitů a okolních subvulkanitů (vzorky odebrány v lomu Bučník na první etáži z jz. stěny a na druhé etáži z jjz. stěny). Obsahy minerálů ve vzorcích byly určeny na základě planimetrické analýzy výbrusů (průměr ze 7 vzorků, v každém 1 500-2 000 bodů). Pro analýzy chemismu minerálů byly vybrány strukturně odlišné typy xenolitů a hostitelské neovulkanity 
odpovídající trachyandezitu. Vlastní analýzy byly provedeny na elektronové mikrosondě Cameca SX-100 na Společném pracovišti elektronové mikrosondy a mikroanalýzy ÚGV PřF MU Brno a České geologické služby (analytici dr. Petr Gadas a Mgr. Jakub Haifler) za následujících podmínek: vlnově disperzní mód (WDX), urychlovací napětí $15 \mathrm{kV}$, proud elektronového svazku $10 \mathrm{nA}$ a průměr svazku 5-7 $\mu \mathrm{m}$. Při analýze silikátů byly použity následující standardy: albit $(\mathrm{Na})$, sanidin $(\mathrm{Si}, \mathrm{Al}, \mathrm{K})$, fluorapatit $(\mathrm{P})$, olivín $(\mathrm{Mg})$, wollastonit $(\mathrm{Ca}), \mathrm{SrSO}_{4}(\mathrm{Sr})$, baryt $(\mathrm{Ba}), \mathrm{ScVO}_{4}$ $(\mathrm{Sc})$, titanit $(\mathrm{Ti})$, chromit $(\mathrm{Cr})$, almandin $(\mathrm{Fe})$, spessartin $(\mathrm{Mn}), \mathrm{Ni}_{2} \mathrm{SiO}_{4}(\mathrm{Ni})$, gahnit $(\mathrm{Zn})$, vanadinit $(\mathrm{Pb}, \mathrm{V}, \mathrm{Cl})$ a topaz $(\mathrm{F})$. Apatit byl analyzován za využití standardů: albit $(\mathrm{Na})$, andalusit $(\mathrm{Si})$, fluorapatit $(\mathrm{P})$, wollastonit $(\mathrm{Ca})$, $\mathrm{SrSO}_{4}(\mathrm{Sr}, \mathrm{S})$, anatas $(\mathrm{Ti})$, almandin $(\mathrm{Fe}), \mathrm{Mn}_{2} \mathrm{SiO}_{4}(\mathrm{Mn})$, lammerit (As), YAG (Y), $\mathrm{LaPO}_{4}(\mathrm{La}), \mathrm{CePO}_{4}(\mathrm{Ce}), \mathrm{PrPO}_{4}$ (Pr), $\mathrm{NdPO}_{4}(\mathrm{Nd}), \mathrm{CaTh}\left(\mathrm{PO}_{4}\right)_{2}(\mathrm{Th})$, uran (U), topaz $(\mathrm{F})$ a vanadinit $(\mathrm{Cl})$. Naměřené hodnoty $\mathrm{P}, \mathrm{Sc}, \mathrm{Cr}, \mathrm{Ni}, \mathrm{Zn}, \mathrm{Sr}$ a $\mathrm{Pb}$ u silikátů a Ti, Th, U, Y, Pr, As a Sr u apatitu byly pod mezí stanovitelnosti. Obsahy prvků byly přepočteny PAP korekcí (Pouchou, Pichoir 1985). Empirické vzorce minerálů byly přepočítány na následující počty kyslíků ve vzorcové jednotce: olivín (4), pyroxeny (6), amfiboly (23), biotit (22), chlorit (14), živce (8), karbonáty (3), ilmenit (3), rutil (2). $\mathrm{Fe}^{3+}$ bylo dopočteno podle stechiometrie, v př́padě titanitu, pyroxenu a allanitu s pomocí normalizace na sumu 3, 4 a 8 kationtů ve vzorci. Amfiboly byly vyhodnoceny podle klasifikace Leakeho et al. (1997). Empirické vzorce amfibolů a trojmocné železo byly počítány metodou 13eCNK (Schumacher 1996). Pyroxeny byly klasifikovány podle Morimota et al. (1988). Pro biotity byla použita klasifikace Riedera et al. (1998) a pro chlority Baylisse (1975). Empirické vzorce apatitu byly normalizovány na sumu 13 aniontů ve vzorcové jednotce.

\section{Výsledky}

\section{Petrografie xenolitů}

Studované xenolity tvoří v neovulkanitech nápadné enklávy nepravidelného tvaru $\mathrm{s}$ velikostí $\mathrm{v}$ řádu $\mathrm{cm}$ až prvních dm (obr. 2), které se od hostitelských hornin výrazně liší svou stavbou. Xenolity jsou především hrubozrnné, méně pak stř̌edně zrnité (výjimečně byly nalezeny i drobnozrnné až jemnozrnné typy). Textura xenolitů je všesměrně zrnitá a kompaktní. Jejich struktura je holokrystalická, stejnoměrně zrnitá a gabrově zrnitá s přechody do poikilitické. Nejhojněji jsou v xenolitech zastoupeny makroskopicky šedobílé až bílé živce ( 40-55 obj. \%). Primární magmatický plagioklas vytváří převážně hypautomorfně omezené, dokonale štěpné, tlusté tabulky o velikosti až $4 \mathrm{~mm}$ s četnými prasklinami a slabými projevy argilitizace. Při pozorování se zasunutým analyzátorem vykazují tabulky nízký dvojlom a polysyntetické dvojčatění. Plagioklasy odpovídají chemickým složením andezínu až labradoritu $\left(\mathrm{An}_{44-55}\right.$, obr. 3a, tab. 1) a většinou vykazují slabou normální růstovou zonálností (střed mírně bazičtější než okraj). Ve vzorcích se vzácně vyskytují také plagioklasy s výrazně vyšší bazicitou (labradorit až bytownit; $A_{64-72}$, obr. $3 a$, tab. 1) v podobě drobných okrouhlých nebo lištovitých inkluzí v amfibolech (obr. 4a)

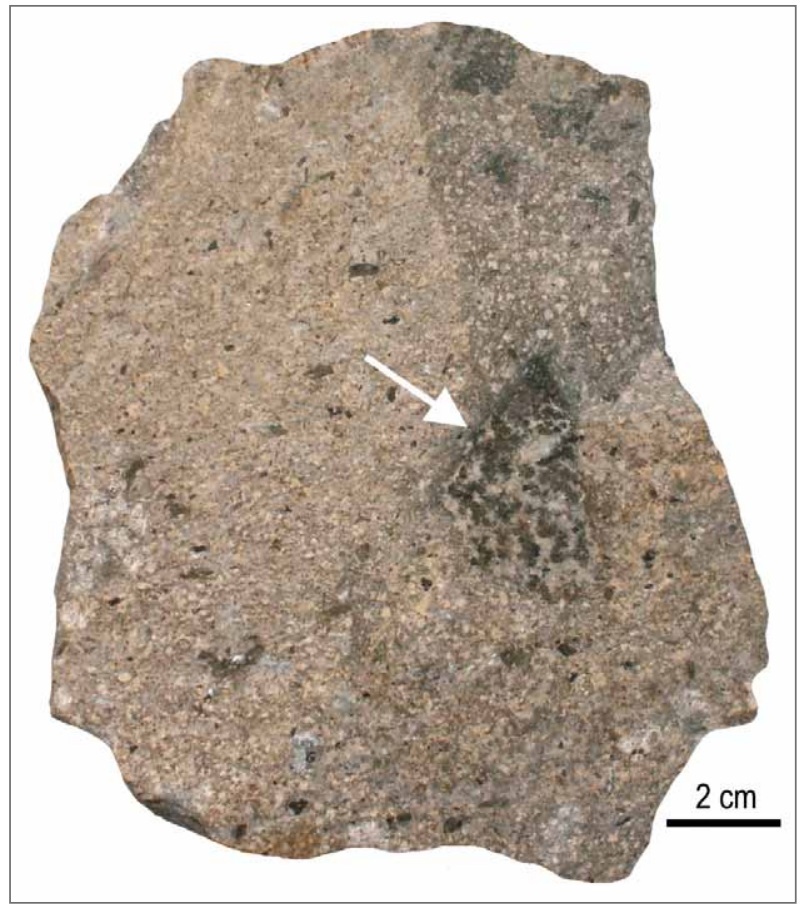

Obr. 2: Hrubozrnný xenolit v propylitizovaném trachyandezitu. Fig. 2: Coarse-grained xenolith in propylitised trachyandesite.

a nepravidelná zrna K-živce $\left(\mathrm{Ab}_{13-20} \mathrm{Or}_{77-86} \mathrm{An}_{01-03}\right)$. Tmavé minerály jsou reprezentovány zejména právě amfibolem ( 20-30 obj. \%), který tvoří černé sloupce o velikosti až 3,5 mm nebo nepravidelná zrna s hypautomorfním až xenomorfním omezením a dobrou štěpností podle $\{110\}$. $\mathrm{Na}$ okrajích a trhlinách zrn se projevuje v různém stupni chloritizace. Ve výbrusu jsou amfiboly silně pleochroické (ve směru X - světle žlutohnědá, Y - tmavě žlutohnědá, $\mathrm{Z}$ - hnědočervená), se středním dvojlomem a bez patrné zonálnosti. Svým chemismem odpovídají magneziohastingsitu, výjimečně pargasitu $\left(\mathrm{X}_{\mathrm{Mg}}=0,64-0,75 ; \mathrm{Si}=\right.$ 6,09-6,29 apfu; $\mathrm{Ti}=0,30-0,42 \mathrm{apfu} ; \mathrm{K}+\mathrm{Na}=0,79-0,97$ apfu; obr. 3b, tab. 2). Amfiboly uzavírají mimo výše zmíněných intermediárních až bazických plagioklasů inkluze olivínu, pyroxen, apatit a opakní zrna. Olivín byl pozorován pouze $\mathrm{v}$ jediném př́padě $\mathrm{v}$ anomálně mafické partii xenolitu. Inkluze má podobu hypautomorfně omezeného krátkého sloupce či tlusté tabulky o délce $25 \mu \mathrm{m} s$ obsahem forsteritové komponenty $64 \mathrm{~mol} \%$ (tab. 2). Pyroxeny jsou v hornině př́tomny v objemu do $\sim 8 \mathrm{obj} . \%$ ve formě silně přeměněných xenomorfních reliktů obklopených amfibolem. Barva reliktů je v rovinně polarizovaném světle krémově bílá, nazelenalá až světle hnědá, bez zřetelného pleochroismu, po zasunutí analyzátoru lze pozorovat střední či nízký dvojlom. Chemické složení pyroxenů odpovídá diopsidu, př́ípadně spočívá na pomezí diopsidu a augitu $\left(\mathrm{X}_{\mathrm{Mg}}=0,70-0,80\right.$; $\mathrm{Ti}=0,01-0,03$ apfu; $\mathrm{Na}=0,03-0,04$ apfu; obr. 3c, 4b, tab. 2). Z primárních fylosilikátů obsahují xenolity malé množství biotitu (do 2 obj. \%). Biotit tvoří hypautomorfně omezené tabulky se silným pleochroismem ve směru $\mathrm{X}$ - světle žlutohnědá, $\mathrm{Y} / \mathrm{Z}$ - tmavě hnědá, které mnohdy uzavírají opakní minerály. Z hlediska chemického složení se jedná o flogopit $\left(\mathrm{X}_{\mathrm{Mg}}=0,58-0,65 ; \mathrm{Si}=5,51-5,60 ;\right.$ obr. $3 \mathrm{~d}$, 


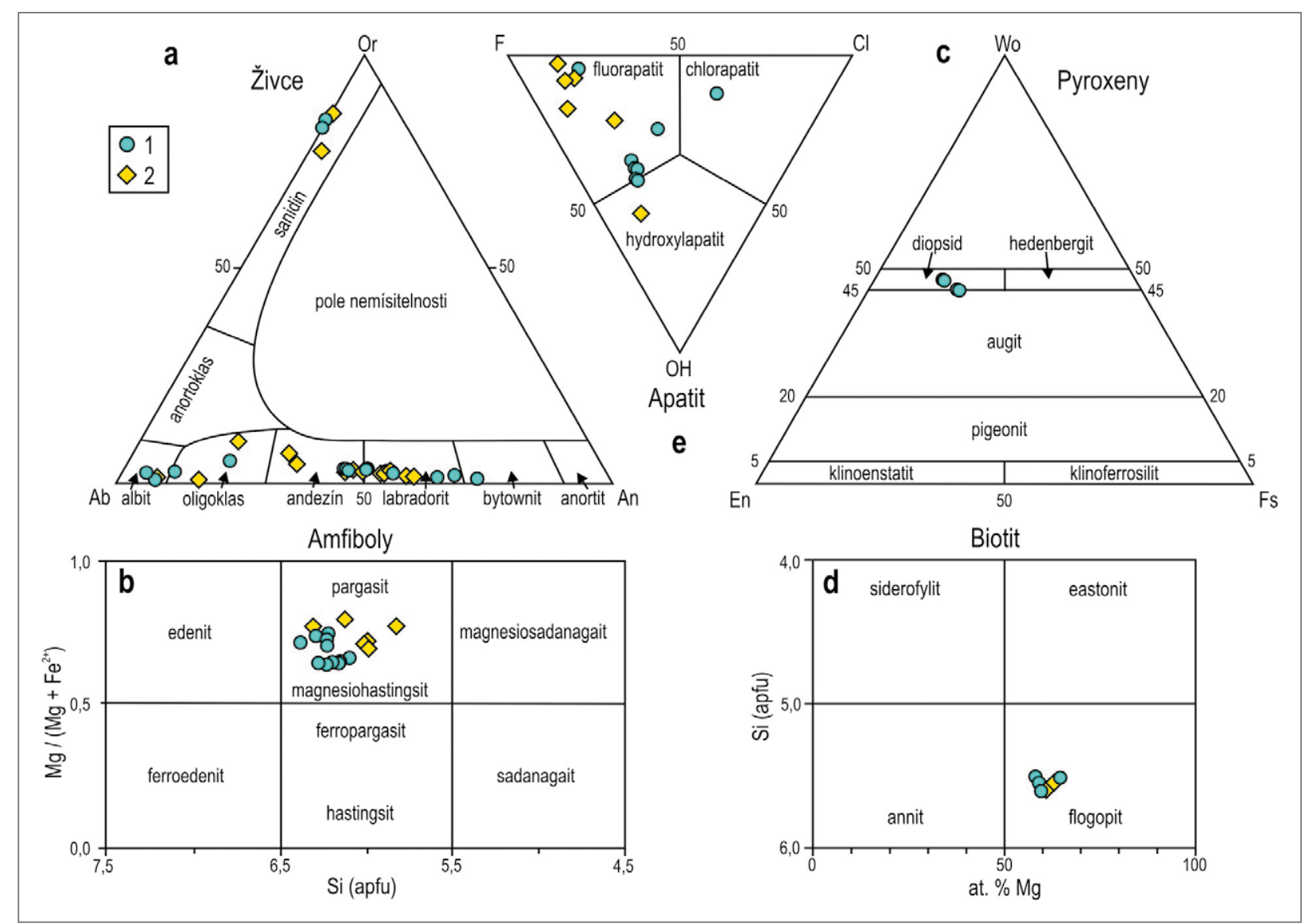

Obr. 3: Klasifikační diagramy znázorňující chemické složení (a) živců, (b) amfibolů, (c) pyroxenů, (d) biotitu a (e) apatitu ze studovaných (1) xenolitů a (2) hostitelských trachyandezitů.

Fig. 3: Classification plots with chemical composition of (a) feldspars, (b) amphiboles, (c) pyroxenes, (d) biotite and (e) apatite from studied (1) xenoliths and host (2) trachyandesites.

Tab. 1: Reprezentativní analýzy chemického složení primárních živců ze studovaných xenolitů (XE) a trachyandezitů (TA). Tab. 1: Representative compositions of primary feldspars from studied xenoliths (XE) and trachyandesites (TA).

\begin{tabular}{|l|c|c|c|c|c|c|c|c|c|}
\hline $\mathrm{Vz} /$ an. & $\mathrm{XE} / \mathrm{XX}$ & $\mathrm{XE} / \mathrm{YY}$ & $\mathrm{XE} / \mathrm{ZZ}$ & $\mathrm{XE} / 22$ & $\mathrm{XE} / 46$ & $\mathrm{XE} / 47$ & $\mathrm{TA} / 3$ & $\mathrm{TA} / 4$ & $\mathrm{TA} / 16$ \\
\hline $\mathrm{Minerál}$ & labradorit & bytownit & labradorit & labradorit & labradorit & andezín & labradorit & andezín & andezín \\
\hline Popis & inkluze & inkluze & inkluze & lišta & lišta stř. & lišta okr. & fen. stř. & fen. okr. & zk. hm. \\
\hline $\mathrm{SiO}_{2}$ & 52,71 & 49,75 & 50,23 & 53,80 & 54,31 & 56,05 & 55,71 & 56,93 & 59,92 \\
\hline $\mathrm{Al}_{2} \mathrm{O}_{3}$ & 29,59 & 31,04 & 27,36 & 27,76 & 27,61 & 26,24 & 27,37 & 26,84 & 24,54 \\
\hline $\mathrm{Fe}_{2} \mathrm{O}_{3}$ & 0,79 & 1,05 & 3,29 & 0,56 & 0,37 & 0,36 & 0,40 & 0,41 & 0,45 \\
\hline $\mathrm{CaO}$ & 12,91 & 15,11 & 13,40 & 11,31 & 11,04 & 9,49 & 10,66 & 9,65 & 7,14 \\
\hline $\mathrm{SrO}$ & 0,18 & 0,18 & 0,20 & 0,19 & 0,24 & 0,20 & 0,18 & 0,20 & 0,10 \\
\hline $\mathrm{BaO}$ & $\mathrm{dl}$ & $\mathrm{dl}$ & $\mathrm{dl}$ & $\mathrm{dl}$ & $\mathrm{dl}$ & $\mathrm{dl}$ & $\mathrm{dl}$ & $\mathrm{dl}$ & 0,09 \\
\hline $\mathrm{Na}_{2} \mathrm{O}$ & 3,87 & 3,11 & 3,41 & 4,90 & 5,06 & 6,22 & 5,18 & 5,87 & 7,09 \\
\hline $\mathrm{K}_{2} \mathrm{O}$ & 0,18 & 0,13 & 0,27 & 0,32 & 0,46 & 0,57 & 0,34 & 0,52 & 0,75 \\
\hline $\mathrm{Suma}$ & 100,23 & 100,37 & 98,17 & 98,85 & 99,11 & 99,13 & 99,85 & 100,41 & 100,08 \\
\hline $\mathrm{Si}$ & 2,390 & 2,275 & 2,357 & 2,466 & 2,482 & 2,554 & 2,518 & 2,555 & 2,681 \\
\hline $\mathrm{Al}$ & 1,581 & 1,673 & 1,513 & 1,500 & 1,487 & 1,409 & 1,458 & 1,420 & 1,294 \\
\hline $\mathrm{Fe}{ }^{3+}$ & 0,027 & 0,036 & 0,116 & 0,019 & 0,013 & 0,012 & 0,014 & 0,014 & 0,015 \\
\hline $\mathrm{Ca}$ & 0,627 & 0,741 & 0,674 & 0,556 & 0,541 & 0,463 & 0,516 & 0,464 & 0,342 \\
\hline $\mathrm{Sr}$ & 0,005 & 0,005 & 0,005 & 0,005 & 0,006 & 0,005 & 0,005 & 0,005 & 0,003 \\
\hline $\mathrm{Ba}$ & $\mathrm{dl}$ & $\mathrm{dl}$ & $\mathrm{dl}$ & $\mathrm{dl}$ & $\mathrm{dl}$ & $\mathrm{dl}$ & $\mathrm{dl}$ & $\mathrm{dl}$ & 0,002 \\
\hline $\mathrm{Na}$ & 0,340 & 0,275 & 0,310 & 0,436 & 0,449 & 0,549 & 0,454 & 0,511 & 0,615 \\
\hline $\mathrm{K}$ & 0,011 & 0,008 & 0,016 & 0,019 & 0,027 & 0,033 & 0,020 & 0,030 & 0,043 \\
\hline$\Sigma \mathrm{kat}$ & 4,981 & 5,012 & 4,992 & 5,001 & 5,005 & 5,026 & 4,983 & 4,999 & 4,994 \\
\hline $\mathrm{Ab}$ & 34,8 & 26,9 & 31,0 & 43,1 & 44,1 & 52,5 & 45,9 & 50,9 & 61,5 \\
\hline $\mathrm{Or}$ & 1,1 & 0,7 & 1,6 & 1,9 & 2,7 & 3,2 & 2,0 & 2,9 & 4,3 \\
\hline $\mathrm{An}$ & 64,1 & 72,3 & 67,4 & 55,0 & 53,2 & 44,3 & 52,1 & 46,2 & 34,2 \\
\hline
\end{tabular}

*dl - pod mezí detekce, obsahy $\mathrm{P}_{2} \mathrm{O}_{5}$ a $\mathrm{PbO}$ pod mezí detekce př́stroje 
tab. 2). Asociaci primárních minerálů v xenolitu doplňuje apatit, jenž je obvykle přítomen ve vedlejším množství (1-7 obj. \%). Tvoří protáhlé automorfní sloupce o délce až $0,35 \mathrm{~mm}$, které bývají často uzavřeny v amfibolu (obr. 4c). Svým chemismem odpovídá především fluorapatitu ( $\mathrm{F}$ $=0,43-0,77 \mathrm{apfu})$, výjimečně byl zjištěn i hydroxylapatit a chlorapatit (obr. 3e, tab. 3).

Hydrotermální alterace se různou měrou projevuje ve všech studovaných vzorcích xenolitů. Mezi tabulkami primárního andezínu a labradoritu a na trhlinách se objevuje novotvořený kyselý plagioklas $\left(\mathrm{An}_{05-10}\right)$ a ve více alterovaných vzorcích akcesoricky i křemen. $\mathrm{Z}$ dalších přeměn jsou př́tomny chloritizace a karbonatizace, které z tmavých minerálů postihují nejsilněji pyroxen (částečné až úplné pseudomorfózy). Chlorit je nejběžnější sekundární minerál v hornině (10-20 obj. \%). Ve výbrusu tvoří šupinky a lupenité agregáty zelené barvy, které vykazují nízký dvojlom a místy anomální interferenční barvy (levandulově modrou nebo olivově zelenou). Chlority studované $\mathrm{z}$ hlediska chemického složení odpovídají klinochloru $\left(\mathrm{X}_{\mathrm{Mg}}=0,55-0,67 ; \mathrm{Si}=3,13-3,29 \mathrm{apfu}\right)$. Obsah karbonátů v xenolitech se pohybuje $\mathrm{v}$ rozmezí $\sim 0,5-2,5$ obj. \%, tvoří žilky a podobně jako chlority zatlačují primární mafické minerály, především pyroxen. $\mathrm{V}$ mikroskopických preparátech lze pozorovat nepravidelná xenomorfně omezená zrna s dokonalou štěpností dle romboedru a vysokým dvojlomem. Jedná se převážně o kalcit: $(\mathrm{Ca} /(\mathrm{Ca}+\mathrm{Fe}+\mathrm{Mn}+\mathrm{Mg})=0,84-0,99)$, avšak v pseudomorfózách po pyroxenu byl zaznamenán i siderit (Fe/ $(\mathrm{Fe}+\mathrm{Mn}+\mathrm{Mg}+\mathrm{Ca})=0,81)$. Kromě chloritu a karbonátů lze $\mathrm{v}$ pseudomorfózách pozorovat hypautomorfní až xenomorfní lišty ilmenitu s 3-14 mol. \% pyrofanitové komponenty, který je nahrazován rutilem a titanitem (obr. 4c) s mírně zvýšenými obsahy $\mathrm{Nb}$ (rutil obsahuje až $4,8 \mathrm{hm} . \% \mathrm{Nb}_{2} \mathrm{O}_{5}$, titanit 2,0 hm. \%). Dále jsou přítomna drobná automorfní i xenomorfní zrnka pyritu a chalkopyritu.
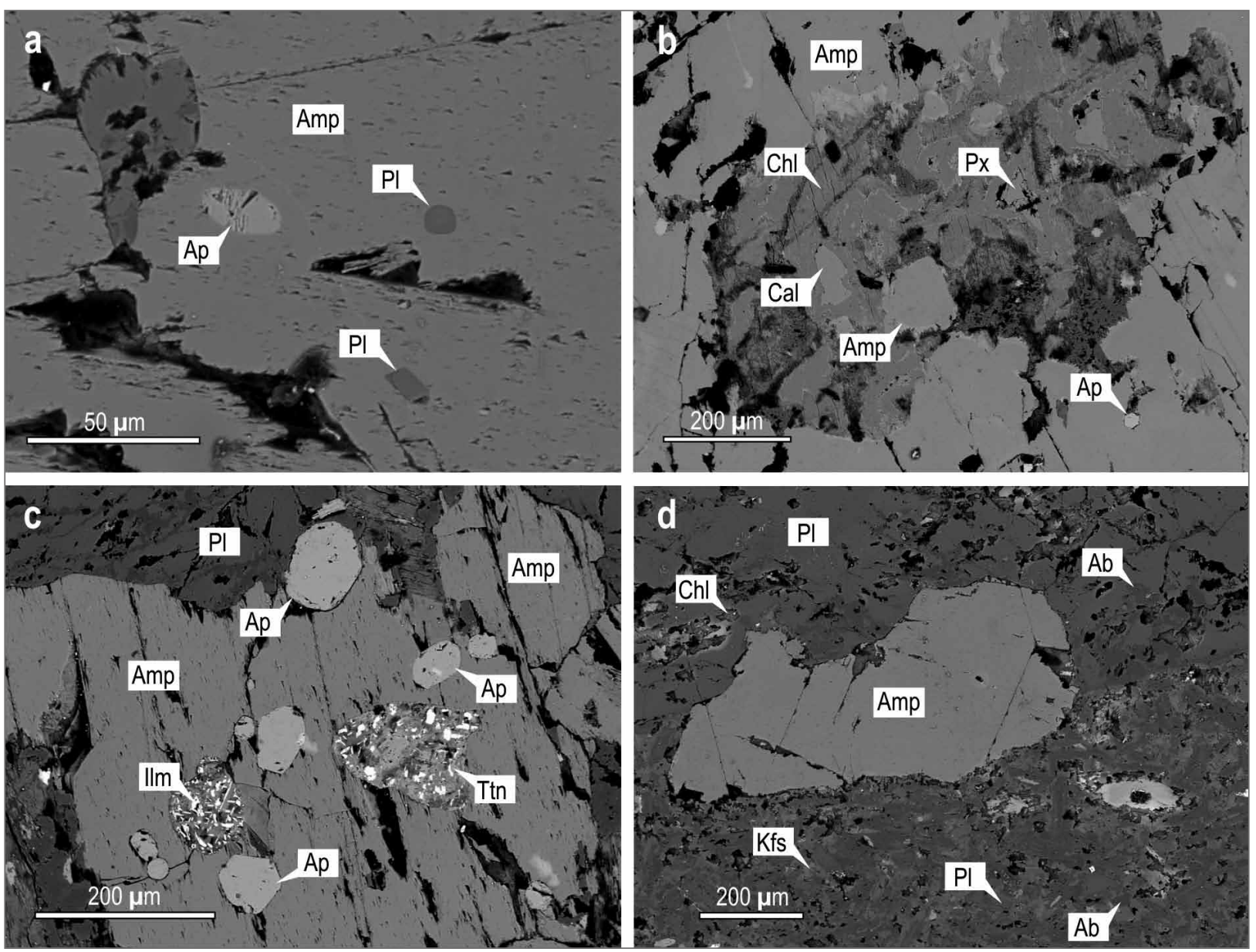

Obr. 4: BSE snímky ze středně až hrubě zrnitých xenolitů (a-c) a rozhraní xenolitu a trachyandezitu (d): a) inkluze labradoritu až bytownitu uzavřené $\mathrm{v}$ amfibolu; b) relikty pyroxenu obklopené amfibolem a produkty alterace; c) inkluze apatitu v amfibolu a pseudomorfózy tvořené karbonátem, chloritem, ilmenitem, rutilem a titanitem; d) absence reakčního lemu mezi xenolitem (nahoře) a jemnozrnnou propylitizovanou základní hmotou trachyandezitu (dole). Zkratky: Ab - albit, Ap - apatit, Amp - amfibol, Cal - kalcit, Chl - chlorit, Ilm - ilmenit, Kfs - K-živec, Pl - plagioklas, Ttn - titanit.

Fig. 4: BSE images of medium to coarse-grained xenoliths (a-c) and xenolith-trachyandesite interface (d): a) amphibole enclosing labradorite to bytownite inclusions; b) pyroxene relict surrounded by amphibole and alteration products; c) inclusions of apatite in amphibole and pseudomorphs consisting of carbonate, chlorite, ilmenite, rutile and titanite; $d$ ) absence of a reaction rim between the xenolith (top) and the fine-grained propylitised matrix of trachyandesite (bottom). Abbreviations: Ab - albite, Ap - apatite, Amp - amphibole, Cal - calcite, Chl - chlorite, Ilm - ilmenite, Kfs - K-feldspar, $\mathrm{Pl}$ - plagioclase, Ttn - titanite. 
Tab. 2: Reprezentativní analýzy chemického složení olivínu, pyroxenu, amfibolu a biotitu ze studovaných xenolitů (XE) a trachyandezitů (TA).

Tab. 2: Representative compositions of olivine, pyroxene, amphibole and biotite from studied xenoliths (XE) and trachyandesites (TA).

\begin{tabular}{|c|c|c|c|c|c|c|c|c|c|}
\hline Vz./an. & $\mathrm{XE} / \mathrm{EE}$ & $\mathrm{XE} / 62$ & $\mathrm{XE} / 36$ & $\mathrm{XE} / 49$ & $\mathrm{XE} / 50$ & $\mathrm{TA} / 2$ & $\mathrm{TA} / 87$ & $\mathrm{XE} / 40$ & $\mathrm{TA} / 6$ \\
\hline Minerál & olivín & diopsid & Mg-hast. & Mg-hast. & pargasit & Mg-hast. & pargasit & flogopit & flogopit \\
\hline Popis & inkluze & relikt & okraj & střed & okraj & fen. stř. & fen. střr. & zrno & fenokryst \\
\hline $\mathrm{SiO}_{2}$ & 36,89 & 49,84 & 41,06 & 41,09 & 40,85 & 43,31 & 40,36 & 36,08 & 37,24 \\
\hline $\mathrm{TiO}_{2}$ & 0,05 & 1,19 & 3,32 & 2,95 & 3,70 & 2,75 & 2,77 & 4,55 & 4,54 \\
\hline $\mathrm{Al}_{2} \mathrm{O}_{3}$ & $\mathrm{dl}$ & 3,88 & 12,03 & 11,93 & 12,24 & 11,00 & 15,47 & 14,63 & 14,27 \\
\hline $\mathrm{V}_{2} \mathrm{O}_{3}$ & $\mathrm{dl}$ & $\mathrm{dl}$ & 0,09 & 0,10 & 0,08 & 0,06 & 0,11 & $\mathrm{dl}$ & $\mathrm{dl}$ \\
\hline $\mathrm{Fe}_{2} \mathrm{O}_{3}$ & 0,00 & 2,58 & 4,16 & 4,44 & 2,19 & 5,91 & 3,11 & 0,00 & 0,00 \\
\hline $\mathrm{FeO}$ & 30,60 & 5,86 & 10,85 & 10,72 & 11,33 & 7,25 & 7,30 & 16,61 & 15,91 \\
\hline $\mathrm{MnO}$ & 0,56 & 0,25 & 0,24 & 0,25 & 0,20 & 0,23 & 0,09 & 0,11 & 0,17 \\
\hline $\mathrm{MgO}$ & 29,95 & 13,04 & 11,20 & 10,97 & 11,34 & 13,56 & 13,96 & 12,94 & 13,95 \\
\hline $\mathrm{CaO}$ & 0,27 & 22,20 & 11,31 & 11,07 & 11,39 & 11,40 & 12,87 & 0,12 & 0,08 \\
\hline $\mathrm{BaO}$ & $\mathrm{dl}$ & $\mathrm{dl}$ & 0,14 & 0,16 & 0,17 & 0,10 & 0,15 & 1,22 & 0,91 \\
\hline $\mathrm{Na}_{2} \mathrm{O}$ & $\mathrm{dl}$ & 0,52 & 2,31 & 2,22 & 2,43 & 2,33 & 2,32 & 0,81 & 0,78 \\
\hline $\mathrm{K}_{2} \mathrm{O}$ & $\mathrm{dl}$ & $\mathrm{dl}$ & 1,06 & 1,29 & 0,89 & 0,95 & 1,40 & 8,18 & 8,31 \\
\hline $\mathrm{F}$ & $\mathrm{dl}$ & 0,12 & 0,21 & 0,23 & 0,21 & 0,23 & 0,20 & 0,37 & 0,61 \\
\hline $\mathrm{Cl}$ & $\mathrm{dl}$ & $\mathrm{dl}$ & 0,08 & 0,11 & 0,06 & 0,11 & 0,03 & 0,17 & 0,14 \\
\hline $\mathrm{O}=\mathrm{F}+\mathrm{Cl}$ & 0,00 & $-0,05$ & $-0,10$ & $-0,12$ & $-0,10$ & $-0,12$ & $-0,09$ & $-0,19$ & $-0,29$ \\
\hline Suma & 98,32 & 99,42 & 97,95 & 97,38 & 96,97 & 99,07 & 100,03 & 95,59 & 96,62 \\
\hline $\mathrm{Si}$ & 1,019 & 1,870 & 6,138 & 6,185 & 6,147 & 6,301 & 5,820 & 5,511 & 5,604 \\
\hline $\mathrm{Ti}$ & 0,001 & 0,033 & 0,374 & 0,334 & 0,419 & 0,301 & 0,300 & 0,523 & 0,514 \\
\hline $\mathrm{Al}$ & $\mathrm{dl}$ & 0,172 & 2,120 & 2,116 & 2,171 & 1,886 & 2,629 & 2,634 & 2,531 \\
\hline $\mathrm{V}$ & $\mathrm{dl}$ & $\mathrm{dl}$ & 0,011 & 0,012 & 0,009 & 0,007 & 0,013 & $\mathrm{dl}$ & $\mathrm{dl}$ \\
\hline $\mathrm{Fe}^{3+}$ & 0,000 & 0,073 & 0,467 & 0,503 & 0,248 & 0,647 & 0,337 & 0,000 & 0,000 \\
\hline $\mathrm{Fe}^{2+}$ & 0,707 & 0,184 & 1,357 & 1,349 & 1,426 & 0,882 & 0,880 & 2,121 & 2,002 \\
\hline $\mathrm{Mn}$ & 0,013 & 0,008 & 0,031 & 0,031 & 0,025 & 0,028 & 0,011 & 0,014 & 0,021 \\
\hline $\mathrm{Mg}$ & 1,233 & 0,730 & 2,495 & 2,460 & 2,544 & 2,942 & 3,002 & 2,945 & 3,130 \\
\hline $\mathrm{Ca}$ & 0,008 & 0,893 & 1,812 & 1,785 & 1,837 & 1,777 & 1,988 & 0,020 & 0,012 \\
\hline $\mathrm{Ba}$ & $\mathrm{dl}$ & $\mathrm{dl}$ & 0,008 & 0,010 & 0,010 & 0,006 & 0,008 & 0,073 & 0,054 \\
\hline $\mathrm{Na}$ & $\mathrm{dl}$ & 0,038 & 0,669 & 0,649 & 0,709 & 0,658 & 0,647 & 0,240 & 0,227 \\
\hline $\mathrm{K}$ & $\mathrm{dl}$ & $\mathrm{dl}$ & 0,202 & 0,247 & 0,171 & 0,176 & 0,258 & 1,594 & 1,596 \\
\hline $\mathrm{F}$ & $\mathrm{dl}$ & 0,014 & 0,097 & 0,107 & 0,101 & 0,106 & 0,093 & 0,177 & 0,289 \\
\hline $\mathrm{Cl}$ & $\mathrm{dl}$ & $\mathrm{dl}$ & 0,020 & 0,027 & 0,016 & 0,028 & 0,008 & 0,043 & 0,037 \\
\hline$\Sigma$ kat. & 2,980 & 4,000 & 15,683 & 15,681 & 15,717 & 15,612 & 15,893 & 15,676 & 15,691 \\
\hline
\end{tabular}

*dl - pod mezí detekce, obsahy $\mathrm{Sc}_{2} \mathrm{O}_{3}, \mathrm{Cr}_{2} \mathrm{O}_{3}, \mathrm{NiO}, \mathrm{ZnO}$ a SrO pod mezí detekce př́istroje

\section{Petrografie hostitelských subvulkanických hornin}

Hostitelský trachyandezit se vyznačuje nestejnoměrně zrnitou strukturou. Porfyrické vyrostlice jsou uspořádány všesměrně, ale místy se seskupují do shluků (zejména vyrostlice plagioklasu). Převažuje plagioklas (18-25\% z celkového objemu horniny) a amfibol (7-15 obj. \%), v menším množství jsou přítomny také relikty pyroxenu $(<2,5 \mathrm{obj}$. \%), biotit $(<5 \mathrm{obj}$. \%) a apatit (<1 obj. \%). Fenokrysty plagioklasu mají podobu automorfně či hypautomorfně omezených tabulek o velikosti až $5 \mathrm{~mm}$. Tabulky jeví známky magmatické koroze, jsou rozpraskané a podél prasklin argilitizované. Vykazují obvykle slabou normální růstovou zonálnost (střed $\mathrm{An}_{48-59}$, okraj $\mathrm{An}_{45-48}$; tab. 1), v některých prrípadech je zonálnost nevýrazná s jemnými oscilacemi v chemickém složení. Porfyrické vyrostlice amfibolu tvoří makroskopicky černé sloupce o délce až $7 \mathrm{~mm}$. Při pozorování v polarizovaném světle ve výbrusu mají podobné vlastnosti, jako amfiboly $\mathrm{v}$ xenolitech. Liší se pouze vyšším stupněm automorfie (dokonale omezené šestiúhelníky v prŕíčném řezu), častou přítomností kontaktního dvojčatění a známek magmatické koroze. Chemismus fenokrystů amfibolů je poměrně homogenní s mírnými oscilacemi, lze je klasifikovat jako magneziohastingsit nebo vzácně pargasit $\left(\mathrm{X}_{\mathrm{Mg}}=\right.$ $0,69-0,79 ; \mathrm{Si}=5,82-6,12 \mathrm{apfu} ; \mathrm{Ti}=0,30-0,41$ apfu; $\mathrm{K}+\mathrm{Na}$ =0,81-0,92 apfu; obr. 3b, tab. 2). Pyroxeny jsou v trachyandezitu vlivem hydrotermální alterace zachovány pouze v podobě ojedinělých reliktů (ve výbrusu se svými vlastnostmi neliší od pyroxenů v xenolitech). Běžné jsou částečné nebo úplné pseudomorfózy po pyroxenu, tvořené zejména chloritem $\left(\mathrm{X}_{\mathrm{Mg}}=0,68 ; \mathrm{Si}=3,34 \mathrm{apfu}\right)$, chemicky čistým kalcitem, kyselým plagioklasem $\left(\mathrm{An}_{20}\right)$ a ilmenitem s 26 mol. \% pyrofanitové komponenty, který byl alterován na titanit. Biotit tvoří v hornině až $2 \mathrm{~mm}$ velké tenké tabulky s dokonalou štěpností podle $\{001\}$ a výrazným pleochroismem (X - žlutohnědá, $\mathrm{Y} / \mathrm{Z}$ - červenohnědá). Chemismem odpovídá flogopitu $\left(\mathrm{X}_{\mathrm{Mg}}=0,61-0,63 ; \mathrm{Si}=\right.$ 5,55-5,56; obr. 3d, tab. 2). Apatit má sloupcovitý vývin $s$ délkou ve směru protažení max. $0,5 \mathrm{~mm}$. Vyskytuje se v základní hmotě, kde vykazuje známky magmatické 
koroze nebo je uzavírán amfibolem či biotitem. Chemicky odpovídá fluorapatitu ( $\mathrm{F}=0,35-0,84 \mathrm{apfu})$, vzácně hydroxylapatitu (obr. 3e, tab. 3).

Jemnozrnná základní hmota (obr. $4 \mathrm{~d}$ ) představuje cca 50-60 obj. \% horniny a je vždy více či méně postižena propylitizací. Skládá se z hypautomorfně omezených tabulek andezínu až labradoritu $\left(\mathrm{An}_{31-57}\right)$. Druhotné minerály zde zastupují xenomorfní nepravidelná zrna albitu až oligoklasu $\left(\mathrm{An}_{07-16}\right)$, lupenité agregáty chloritu $\left(\mathrm{X}_{\mathrm{Mg}}=0,67\right.$; $\mathrm{Si}=3,41 \mathrm{apfu})$, xenomorfní zrna kalcitu $(\mathrm{Ca}=0,91-0,96$ apfu) a křemene a opakní minerály s různým stupněm automorfie (převážně pyrit, méně chalkopyrit a galenit). Akcesoricky jsou v základní hmotě př́tomny také minerály ze skupiny epidotu (allanit). Tvoří xenomorfní zrnka o velikosti do $100 \mu \mathrm{m}$ s výraznou chemickou zonálností. Středy zrn jsou v BSE obraze světlejší $(\Sigma \mathrm{REE}+\mathrm{Y}=0,90$ apfu; $\mathrm{Al}=1,56 \mathrm{apfu})$ než okraje $(\Sigma \mathrm{REE}+\mathrm{Y}=0,57 \mathrm{apfu} ; \mathrm{Al}$ $=1,91 \mathrm{apfu}$ ). Vulkanické sklo není ve vzorcích zachováno, bylo alterováno na směs chloritu a jílových minerálů.

\section{Diskuze}

Studované xenolity odpovídají na základě minerálního složení a stavby jemnozrnným až hrubozrnným pyroxenicko-amfibolickým gabrům až dioritům, v souladu se zjištěními Haškové (2018). Podobné horniny popisuje Krystek $(1955,1958)$ spolu s dioritovými porfyrity a granodiority z Nezdenic, na Bučníku pak tento autor uvádí především amfibolicko-pyroxenický křemenný diorit, biotitický diorit a „leukokrátní diferenciáty“ kř̀emenného dioritu. Na základě chemického složení spadají xenolity v TAS diagramu do pole bazaltů (obr. 5a) a odpovídají tak hlubinným ekvivalentům gabra, resp. monzogabra (Hašková 2018; Buriánek, Kropáč 2019). Klasifikaci znesnadňuje hydrotermální alterace, zejména novotvořené kyselé plagioklasy a křemen.

Xenolity vykazují značnou podobnost v minerálním složení i chemismu hlavních horninotvorných minerálů s hostitelskými neovulkanity na Bučníku. To potvrzují data v této práci i srovnání s daty Štrublíkové (2015), Hroudy et al. (2015), Haškové (2018) a Buriánka a Kropáče (2019). Výjimkou je pouze olivín, který na Bučníku dosud nebyl popsán, ale je znám $\mathrm{z}$ bazičtějších členů asociace uherskobrodských neovulkanitů, zejména $\mathrm{z}$ lomu ve Starém Hrozenkově a $\mathrm{z}$ drobných výskytů v okolí Komni, Bánova a dvora Volenova (Krystek 1955; Nejbert et al. 2012; Hrouda et al. 2015). Xenolity a trachyandezity se tedy liší především strukturou, což pouze odráží jiné podmínky prostředí krystalizace. Podobnosti ve složení xenolitů a hostitelských hornin si všimnul již Krystek (1955, 1958). Sourodost v látkovém složení může být doložena nepřítomností reakčního lemu mezi oběma horninami (obr. 4d) a celkovým chemismem (Hašková 2018; Buriánek, Kropáč 2019). V TAS diagramu leží xenolity na linii mezi alkalickými a subalkalickými magmatity (obr. 5a), což spolu s obdobnou distribucí REE (obr. 5b) dokládá jejich př́slušnost $\mathrm{k}$ neovulkanitům uherskobrodské oblasti (Hašková 2018), které mají geochemicky specifické postavení mezi neovulkanity Českého masivu a slovenských Karpat (Shrbený 1974; Přichystal 1993; Nejbert et al. 2012). Xenolity tedy mohou představovat materiál

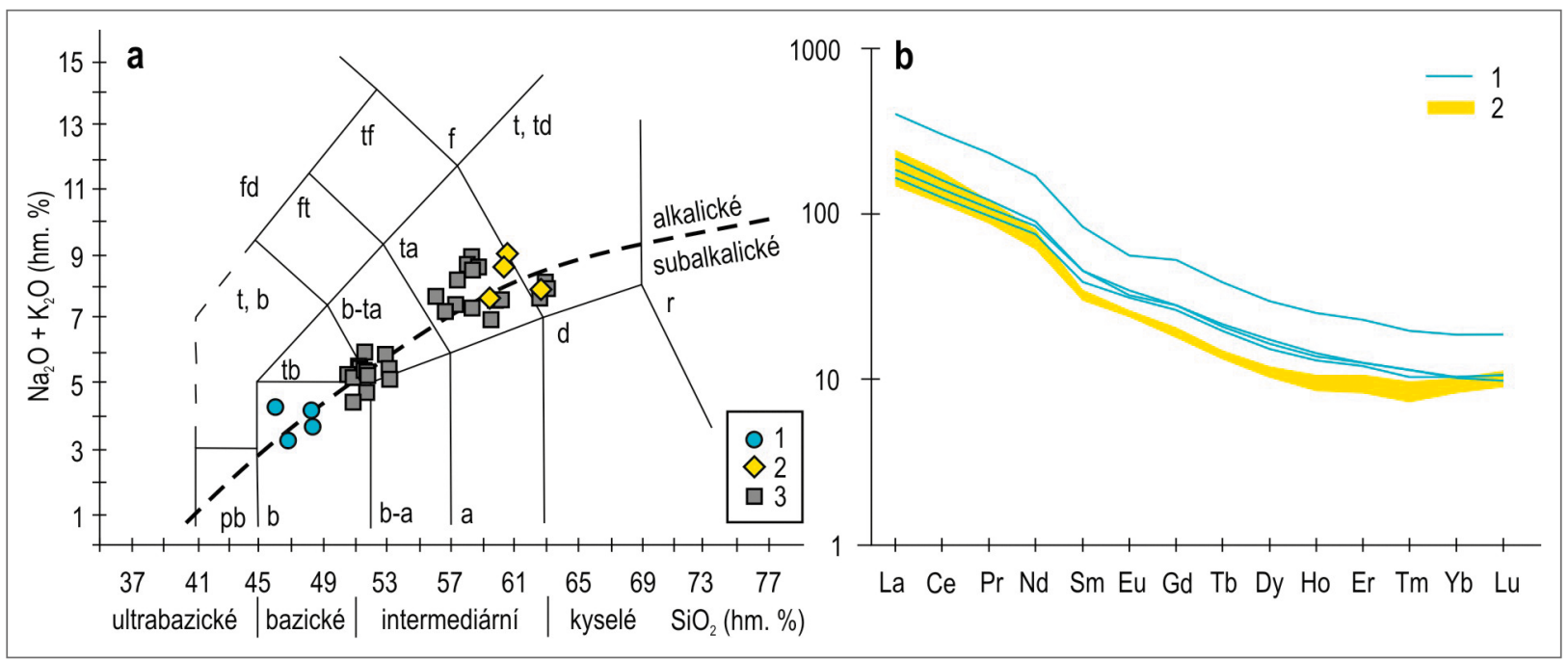

Obr. 5: a) Pozice studovaných vyvřelých hornin z Uherskobrodska v TAS diagramu: (1) xenolity a (2) neovulkanity z Bučníku (Hašková 2018), (3) dříve publikované chemické složení neovulkanitů Uherskobrodska (Krejčí et al. 1990; Fediuk, Gürtlerová 2006; Nejbert et al. 2012; Hrouda et al. 2015). Zkratky: fd - foidit, t, b - tefrit, bazanit, $\mathrm{ft}$ - fonotefrit, tf - tefrifonolit, $\mathrm{f}$ - fonolit, $\mathrm{pb}$ - pikrobazalt, $\mathrm{b}$ - bazalt, tb - trachybazalt, b-ta - bazaltický trachyandezit, ta - trachyandezit, $\mathrm{t}, \mathrm{td}$ - trachyt, trachydacit, b-a - bazaltický andezit, a - andezit, d - dacit, r - ryolit; b) distribuce REE ve studovaných horninách (normalizace na chondrit dle Barrata et al. 2012, data převzata z Haškové (2018): (1) xenolity a (2) neovulkanity z Bučníku.

Fig. 5: a) Position of studied igneous rocks of the Uherský Brod area in TAS diagram, (1) xenoliths and (2) neovolcanites from the Bučník site (Hašková 2018), (3) previously published chemical composition of neovolcanites of the Uherský Brod area (Krejčí et al. 1990; Fediuk, Gürtlerová 2006; Nejbert et al. 2012; Hrouda et al. 2015). Abbreviations: fd - foidite, t, b - tephrite, bazanite, $\mathrm{ft}$ - fonotephrite, $\mathrm{tf}$ - tephrifonolite, $\mathrm{f}$ - fonolite, $\mathrm{pb}$ - picrobasalt, $\mathrm{b}$ - basalt, $\mathrm{tb}$ - trachybasalt, $\mathrm{b}$-ta - basaltic trachyandesite, ta trachyandesite, $\mathrm{t}, \mathrm{td}$ - trachyte, trachydacite, $\mathrm{b}$ - $\mathrm{a}$ - basaltic andesite, $\mathrm{a}$ - andesite, $\mathrm{d}$ - dacite, $\mathrm{r}$ - ryolite; $\mathrm{b}$ ) chondrite-normalized REE abundances for studied rocks (normalization values are from Barrat et al. 2012, data taken from Hašková 2018): (1) xenoliths and (2) neovolcanites from the Bučník site. 
Tab. 3: Reprezentativní analýzy chemického složení apatitu ze studovaných xenolitů (XE) a trachyandezitů (TA). Tab. 3: Representative compositions of apatite from studied xenoliths (XE) and trachyandesites (TA).

\begin{tabular}{|c|c|c|c|c|c|c|c|c|c|}
\hline Vz./an. & $\mathrm{XE} / 27$ & $\mathrm{XE} / 38$ & $\mathrm{XE} / 39$ & $\mathrm{XE} / 51$ & $\mathrm{XE} / 67$ & $\mathrm{XE} / 71$ & $\mathrm{TA} / 7$ & TA/18 & TA/80 \\
\hline Minerál & fluorap. & fluorap. & fluorap. & hydroxyl. & chlorap. & fluorap. & fluorap. & hydroxyl. & fluorap. \\
\hline $\mathrm{SO}_{3}$ & $\mathrm{dl}$ & $\mathrm{dl}$ & 0,06 & 0,07 & 0,36 & 0,10 & 0,05 & 0,14 & 0,25 \\
\hline $\mathrm{P}_{2} \mathrm{O}_{5}$ & 39,93 & 40,43 & 39,65 & 40,39 & 38,70 & 38,47 & 39,36 & 40,21 & 39,99 \\
\hline $\mathrm{SiO}_{2}$ & 0,23 & 0,28 & 0,36 & 0,29 & 0,81 & 0,85 & 0,27 & 0,30 & 0,35 \\
\hline $\mathrm{Y}_{2} \mathrm{O}_{3}$ & $\mathrm{dl}$ & $\mathrm{dl}$ & $\mathrm{dl}$ & $\mathrm{dl}$ & 0,09 & $\mathrm{dl}$ & $\mathrm{dl}$ & $\mathrm{dl}$ & $\mathrm{dl}$ \\
\hline $\mathrm{La}_{2} \mathrm{O}_{3}$ & 0,16 & 0,13 & 0,32 & 0,19 & 0,35 & 0,23 & 0,18 & $\mathrm{dl}$ & $\mathrm{dl}$ \\
\hline $\mathrm{Ce}_{2} \mathrm{O}_{3}$ & 0,34 & 0,39 & 0,46 & 0,41 & 0,67 & 0,41 & 0,45 & 0,15 & 0,22 \\
\hline $\mathrm{Nd}_{2} \mathrm{O}_{3}$ & 0,18 & 0,26 & 0,21 & $\mathrm{dl}$ & 0,21 & $\mathrm{dl}$ & 0,28 & $\mathrm{dl}$ & $\mathrm{dl}$ \\
\hline $\mathrm{FeO}$ & 0,47 & 0,41 & 0,57 & 0,49 & 0,31 & 0,16 & 0,37 & 0,34 & 0,51 \\
\hline $\mathrm{MnO}$ & 0,14 & 0,12 & 0,22 & 0,15 & 0,14 & $\mathrm{dl}$ & 0,23 & $\mathrm{dl}$ & 0,10 \\
\hline $\mathrm{CaO}$ & 53,78 & 53,05 & 52,46 & 52,95 & 53,77 & 54,77 & 53,57 & 54,23 & 55,24 \\
\hline $\mathrm{Na}_{2} \mathrm{O}$ & 0,09 & 0,10 & 0,16 & 0,10 & 0,24 & 0,14 & 0,12 & 0,08 & 0,28 \\
\hline $\mathrm{F}$ & 1,57 & 1,67 & 1,48 & 1,47 & 1,18 & 1,58 & 2,08 & 1,26 & 2,92 \\
\hline $\mathrm{Cl}$ & 1,22 & 1,23 & 1,08 & 1,10 & 3,64 & 2,04 & 1,31 & 0,83 & 0,81 \\
\hline $\mathrm{O}=\mathrm{F}+\mathrm{Cl}$ & $-0,94$ & $-0,98$ & $-0,87$ & $-0,87$ & $-1,32$ & $-1,13$ & $-1,17$ & $-0,72$ & $-1,41$ \\
\hline Suma & 97,17 & 97,10 & 96,15 & 96,75 & 99,14 & 97,62 & 97,10 & 96,82 & 99,27 \\
\hline S & $\mathrm{dl}$ & $\mathrm{dl}$ & 0,004 & 0,005 & 0,023 & 0,006 & 0,003 & 0,009 & 0,016 \\
\hline $\mathrm{P}$ & 2,988 & 3,014 & 2,998 & 3,020 & 2,873 & 2,883 & 2,949 & 3,005 & 2,909 \\
\hline $\mathrm{Si}$ & 0,021 & 0,024 & 0,032 & 0,025 & 0,071 & 0,075 & 0,024 & 0,026 & 0,030 \\
\hline $\mathrm{Y}$ & $\mathrm{dl}$ & $\mathrm{dl}$ & $\mathrm{dl}$ & $\mathrm{dl}$ & 0,004 & $\mathrm{dl}$ & $\mathrm{dl}$ & $\mathrm{dl}$ & $\mathrm{dl}$ \\
\hline $\mathrm{La}$ & 0,005 & 0,004 & 0,010 & 0,006 & 0,011 & 0,007 & 0,006 & $\mathrm{dl}$ & $\mathrm{dl}$ \\
\hline $\mathrm{Ce}$ & 0,011 & 0,013 & 0,015 & 0,013 & 0,022 & 0,013 & 0,015 & 0,005 & 0,007 \\
\hline $\mathrm{Nd}$ & 0,006 & 0,008 & 0,007 & $\mathrm{dl}$ & 0,007 & $\mathrm{dl}$ & 0,009 & $\mathrm{dl}$ & $\mathrm{dl}$ \\
\hline $\mathrm{Fe}$ & 0,034 & 0,030 & 0,043 & 0,036 & 0,022 & 0,012 & 0,027 & 0,025 & 0,037 \\
\hline $\mathrm{Mn}$ & 0,010 & 0,009 & 0,016 & 0,011 & 0,010 & $\mathrm{dl}$ & 0,017 & $\mathrm{dl}$ & 0,007 \\
\hline $\mathrm{Ca}$ & 5,093 & 5,006 & 5,019 & 5,011 & 5,053 & 5,194 & 5,081 & 5,129 & 5,086 \\
\hline $\mathrm{Na}$ & 0,016 & 0,018 & 0,027 & 0,017 & 0,041 & 0,025 & 0,021 & 0,013 & 0,047 \\
\hline $\mathrm{F}$ & 0,439 & 0,464 & 0,419 & 0,411 & 0,326 & 0,442 & 0,581 & 0,351 & 0,793 \\
\hline $\mathrm{Cl}$ & 0,183 & 0,184 & 0,163 & 0,164 & 0,540 & 0,306 & 0,196 & 0,124 & 0,119 \\
\hline$\Sigma$ kat. & 8,184 & 8,126 & 8,171 & 8,146 & 8,138 & 8,216 & 8,153 & 8,213 & 8,139 \\
\hline
\end{tabular}

${ }^{*} \mathrm{dl}$ - pod mezí detekce, obsahy $\mathrm{TiO}_{2}, \mathrm{ThO}_{2}, \mathrm{UO}_{2}, \mathrm{Pr}_{2} \mathrm{O}_{3}, \mathrm{As}_{2} \mathrm{O}_{3}$ a SrO pod mezí detekce prístroje

z hlubších partií stejného magmatického krbu (Hašková 2018) nebo se může jednat o ekvivalenty kumulátových gaber (Buriánek, Kropáč 2019). Této skutečnosti by mohl nasvědčovat zvýšený podíl apatitu $\mathrm{v}$ xenolitech (místy až 7 obj. \%) a prrítomnost mafičtějších enkláv, jakožto i náznaky glomeroporfyrické struktury u neovulkanitů v podobě shlukování fenokrystů.

\section{Závěr}

Xenolity vyvřelých hornin uzavřené v neovulkanickém tělese na Bučníku lze na základě minerálního složení klasifikovat jako jemně až hrubě zrnitá pyroxenicko-amfibolická gabra až diority, resp. monzogabra až monzodiority u silněji alterovaných vzorků. Na jejich složení se podílejí intermediární až bazické plagioklasy a amfiboly (magnesiohastingsit až pargasit), méně jsou př́itomny relikty pyroxenu (diopsid), biotit (flogopit), apatit (převážně fluorapatit) a K-živec. Nově byl na lokalitě objeven olivín jako inkluze v amfibolu. Sekundární minerály reprezentují kyselé plagioklasy, chlority (klinochlor), karbonáty (kalcit, siderit), ilmenit, rutil, titanit, pyrit a vzácněji chalkopyrit. Genetickou př́buznost xenolitů a hostitelských neovulkanitů dokládá podobnost v minerálním složení, chemismu minerálů, shodná geochemická př́slušnost a distribuce REE. Xenolity mohou představovat materiál z hlubších partií magmatického krbu, ale jako pravděpodobnější interpretace se jeví, že se jedná o krystalové kumuláty, tj. ekvivalenty kumulátových gaber.

\section{Poděkování}

Autoři článku děkují recenzentům a editorovi za cenné kritické připomínky, které přispěly k jeho zkvalitnění. Výzkum byl podpořen projekty IGA_PrF_2018_025 a IGA_PrF_2019_017. 


\section{Literatura}

Adamová, M., Krejčí, O., Přichystal, A. (1995). Neovulkanity východně od Uherského Brodu. - Geologické výzkumy na Moravě a ve Slezsku v roce 1994, 12-15.

Barrat, J. A., Zanda, B., Moynier, F., Bollinger, C., Liorzou, C., Bayon, G. (2012). Geochemistry of CI chondrites: major and trace elements, and $\mathrm{Cu}$ and $\mathrm{Zn}$ isotopes. - Geochimica et Cosmochimica Acta, 83, 79-92. https://doi.org/10.1016/j.gca.2011.12.011

Bayliss, P. (1975). Nomenclature of the trioctahedral chlorites. The Canadian Mineralogist, 13, 178-185.

Buriánek, D., Kropáč, K. (2019). Petrogenesis of the Miocene subvolcanic rocks in the Western Outer Carpathians (Southeast Moravia, Czech Republic). - Journal of Geosciences, 64, 105-125.

Fediuk, F., Gürtlerová, P. (2006). Adakitové trendy v andezitoidech jihovýchodní Moravy. - Bulletin mineralogicko-petrologického oddělení Národního muzea v Praze, 13, 11/2005, 121-124.

Hašková, M. (2018). Xenolity vyvřelých hornin v trachyandezitech z lomu Bučník u Komni. - MS, bakalářská práce. Přírodovědecká fakulta Univerzity Palackého v Olomouci. Olomouc.

Hrouda, F., Buriánek, D., Krejčí, O., Chadima, M. (2015). Magnetic fabric and petrology of Miocene sub-volcanic sills and dykes emplaced into the SW Flysch Belt of the West Carpathians (S Moravia, Czech Republic) and their volcanological and tectonic implications. - Journal of Volcanology and Geothermal Research, 290, 23-38. https://doi.org/10.1016/j.jvolgeores.2014.12.001

Krejčí, O. ed. (1990). Základní geologická mapa a Vysvětlivky k základní geologické mapě 1 : 25 000. List 35-121 Bánov. - Archiv České geologické služby. Praha.

Krejčí, O., Poul, I. (2010). Doklady středomiocénní násunové tektoniky v bělokarpatské jednotce flyšového pásma Západních Karpat. - Geologické výzkumy na Moravě a ve Slezsku, 17 (1-2), 58-63.

Krystek, I. (1955). Alkalické vyvřeliny na jihovýchodní Moravě. - Geologické práce, Správy 41, 103-130.

Krystek, I. (1958). Xenolity z alkalických vyvřelin na jihovýchodní Moravě. - Věstník Ústředního ústavu geologického, 33, $246-252$.

Leake, B. E., Woolley, A. R., Arps, C. E. S., Birch, W. D., Gilbert, M. C., Grice, J. D., Hawthorne, F. C., Kato, A., Kisch, H. J., Krivovichev, V. G., Linthout, K., Laird, J., Mandarino, J. A., Maresch, W. V., Nickel, E. H., Rock, N. M. S., Schumacher, J. C., Smith, D. C., Stephenson, N. C. N., Ungaretti, L., Whittaker, E. J. W., Youzhi, G. (1997). Nomenclature of amphiboles: Report of the subcommittee on amphiboles of the international mineralogical association, commission on new minerals and mineral names. - American Mineralogist, 82 (9-10), 1019-1037.

Morimoto, N., Fabries, J., Ferguson, A. K., Ginzburg, I. V., Ross, M., Seifert, F. A., Zussman, J., Aoki, K. (1988). Nomenclature of pyroxenes. - Mineralogical Magazine, 52, 535-550. https://doi.org/10.1180/minmag.1988.052.367.15

Nejbert, K., Jurewicz, E., Macdonald, R. (2012). Potassium-rich magmatism in the Western Outer Carpathians: Magmagenesis in the transitional zone between the European Plate and Carpathian - Pannonian region. - Lithos, 146-147, 34-47. https:// doi.org/10.1016/j.lithos.2012.04.026

Pécskay, Z., Konečný, V., Lexa, J., Přichystal, A. (2002). K/Ar dating of Neogene volcanic rocks in surrounding of Uherský Brod, Moravia. - In: Ulrych, J., Cajz, V., Adamovič, J., Bosák, P. (eds): Hibsch 2002 Symposium, Excursion Guide and Abstracts, 100, Geologický ústav Akademie věd České republiky, Praha.

Picha, F. J., Stráník, Z., Krejčí, O. (2006). Geology and Hydrocarbon Resources of the Outer Western Carpathians and Their Foreland, Czech Republic. - In: Golonka, J., Picha, F. J. (eds): The Carpathians and their foreland: Geology and hydrocarbon resources, 84, 49-175, The American Association of Petroleum Geologists.

Pouchou, J. L., Pichoir, F. (1985). "PAP” ( $\varphi \rho Z)$ procedure for improved quantitative microanalysis. - In: Armstrong J. T. (ed.): Microbeam Analysis, 104-106, San Francisco Press.

Přichystal, A. (1993). Vulkanismus v geologické historii Moravy a Slezska od paleozoika do kvartéru. - In: Přichystal, A., Obstová, V., Suk, M. (eds): Sborník příspěvků k 90. výročí narození prof. dr. K. Zapletala, 59-77, Moravské zemské muzeum a Sekce geologických věd, Př́rodovědecká fakulta Masarykovy univerzity.

Přichystal, A., Repčok, I., Krejčí, O. (1998). Radiometrické datování trachyandezitu od Uherského Brodu (magurská skupina flyšového pásma). - Geologické výzkumy na Moravě a ve Slezsku v r. 1997, 5, 33-34.

Shrbený, O. (1974). The petrochemical relation of the south-Moravian neovolcanic rocks to the neighbouring volcanic areas. Věstník Ústředního ústavu geologického, 49, 275-279.

Schumacher, J. (1996). The estimation of the proportion of ferric iron in the electron microprobe analysis of amphiboles. - The Canadian Mineralogist, 34, 238-246.

Stráník, Z., Menčík, E., Eliáš, M., Adámek, J. (1993). Flyšové pásmo Západních Karpat, autochtonní mesozoikum a paleogén na Moravě a ve Slezsku. - In: Přichystal A., Obstová, V., Suk, M. (eds): Geologie Moravy a Slezska, 107-122. Moravské zemské muzeum a Sekce geologických věd Př́rodovědecké fakulty Masarykovy univerzity.

Stráník, Z., Bubík, M., Čech, S., Švábenická, L. (1996). The Upper Cretaceous in South Moravia. - Věstník Českého geologického ústavu, 71, 1, 1-30.

Štrublíková, V. (2015). Petroarcheologický výzkum zříceniny hradu Komňa v Bílých Karpatech. - MS, bakalářská práce, Přírodovědecká fakulta Univerzity Palackého v Olomouci. Olomouc.

Švábenická, L., Bubík, M., Krejčí, O., Stráník, Z. (1997). Stratigraphy of Cretaceous sediments of the Magura Group of nappes in Moravia (Czech Republic). - Geologica Carpathica, 48, 3, 179-191.

Rieder, M., Cavazzini, G., Dyakonov, Y., Frank-Kamenetskii, V. A., Gottardi, G., Guggenheim, S., Koval, P. V., Müller, G., Neiva, A. M. R., Radoslovich, E. W., Robert, J. L., Sassi, F. P., Takeda, H., Weiss, Z. (1998). Nomenclature of micas. - The Canadian Mineralogist, 36, 41-48.

Ulmanová, J. (2015). Podmínky vzniku vybraných mineralizací z lomu Bučník u Komni. - MS, bakalářská práce, Př́rodovědecká fakulta Univerzity Palackého v Olomouci. Olomouc. 